\title{
Mineralogical, chemical and textural study of roman mortars for their restoration case of the historic site of Volubilis (Morocco)
}

\author{
Abdelmalek AMMARI ${ }^{1 *}$, Abdelilah DEKAYIR ${ }^{2}$, M.A.DOS-BENNANI ${ }^{3}$ \\ ${ }^{1}$ LMM, Dept. of physics, Mohammed V University, Rabat, Morocco \\ ${ }^{2}$ Equipe Géotech, Dept. of geologie, BP 11201Zitoune, Meknes, Morocco \\ ${ }^{3}$ LPEE, Bassatine, Meknes, Morocco
}

Corresponding author: E-mail: Abdelmalek09@gmail.com

Keywords: Mortar Mosaic, Characterization, Catering, Mechanical Testing, Volubilis

\begin{abstract}
The objective of this study is to conduct a mineralogical and chemical characterization of the mortars Roman archaeological site of Volubilis to rebuild spare mortars for restoration. Samples of mortar, broken tile palate garden, and pavement mosaic Falavius Germanus. The analysis by X-ray diffraction reveals that the coarse mortar Flavius Germanus is made of quartz and calcite, with feldspar and probably, mica and dolomite in small amounts. The binder end is formed calcite and quartz. However, the broken tile mortar is formed by coarse particles, clay base mixed with a binder phase dominated by calcite. These results allowed us to reformulate spare mortars for the restoration of damaged Roman mosaics, the mortars are made up by $63.6 \%$ of lime and $36.4 \%$ of sand(with (4.19\% of large grain, $71,04 \%$ of coarse sand, $24.22 \%$, of fine sand and $0.55 \%$ fines parts). The performance of these mortars was tested by mechanical testing.
\end{abstract}

\section{Introduction}

Roman mosaics [1-2] Volubilis are precious works of leaders. Since its ranking on the list of UNESCO World Heritage in 1987, this city continues to receive special attention. Roman artists have exploited the geological formations around the city for the construction and decoration of mosaics, through different materials. Building mortars, including those of the mosaics and the baths built pavements show the very advanced states of deterioration related to the phenomena of weathering and soil instability of the city. The purpose of this research is first to proceed to a mineralogical and chemical characterization of a mean particle size of mortar samples from the Roman mosaic (Flavius Germanus) and another from the Baths of Galliens. Then there is the alternative of recreation mortars with similar characteristics to the former moat.

\section{Materials and methods}

In the mosaic of Flavius Germanus (FG), mortar samples were collected in the nucleus layer (FGMG) and end binder (FGLF), while the mortar broken tile comes from basins Gallien baths. The latter was used by the Romans in coating walls thermal baths.

The mineralogy of the mortars is analyzed by X-ray powder (XRD) and the Fourier transformed infrared spectroscopy (FTIR) [2].

\section{A. Mineralogy and chemical composition of Roman mortars}

\section{A.1 Mineralogy and chemistry of the nucleus and binding end mineralogy}

The XRD spectra of the nucleus FGMG show in (Fig.1a). It is consisted mainly of quartz and calcite, with traces of feldspar and probably mica and dolomite. FTIR spectra of this mortar is presented in (Fig. 1 :b). The bands located at $(1797,1427,874,712 \mathrm{~cm}-1)$ are related to the calcite. The bands situated at $(1034,778,796 \mathrm{~cm}-1)$ are assigned to the vibrations bands of quartz. The bands located at $(3695,3620,1034,796,767 \mathrm{~cm}-1)$ are related to the kaolinite. The last bands located at $(2982,2924$, 
$2913,2874 \mathrm{~cm}-1$ ) are due to the presence of $\mathrm{OH}$ groups probably related to humic and fulvic acids and caused by root activity $[2,3]$.

While the analysis of the end binder (FGLF) shows spectra superimposed with those of coarse mortar (Fig. FGLF 1.a and 1.b FGLF) with very small quartz grains cemented by calcite. Unlike the coarse mortar, this binder is richer in quartz, calcite that, as evidenced by the chemical analysis.
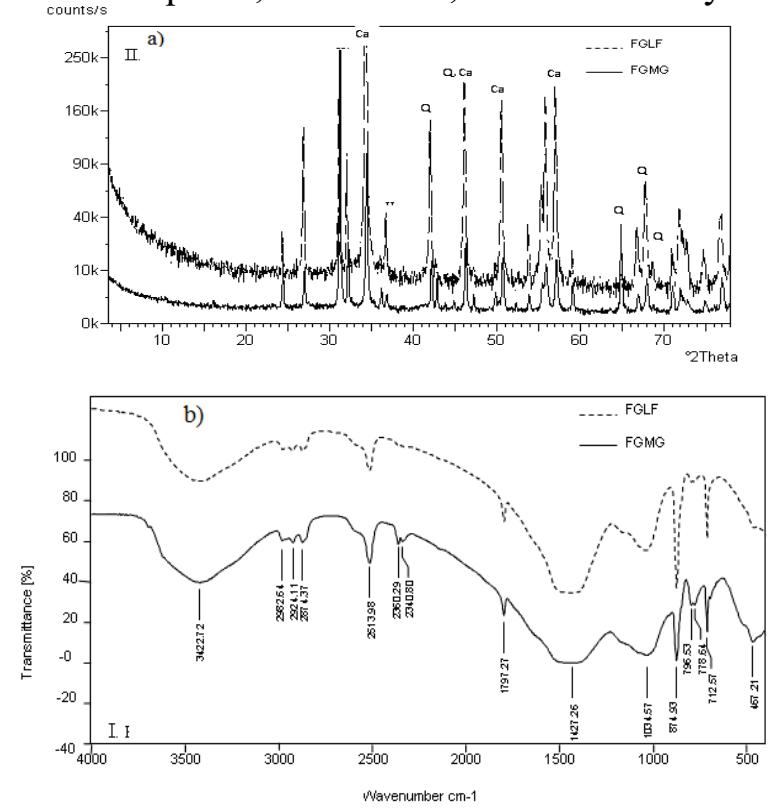

Fig. 1: a) XRD spectra of the coarse mortar (FGMG) and binder end (FGLF). (Q: quartz; Ca: calcite; D: dolomite; F: feldspar M: Mica). b) FTIR spectra of: Coarse mortar (FGMG) and the end binder (FGLF) [2]

\section{A.2 Chemical analysis and mortar outlet}

The chemical analyzes of the coarse mortar (FGMG) show a SiO2 content (35.63\%) high compared with that of the end binder (FGLF) due to the quartz concentration. Conversely, the binder end shows an enrichment in $\mathrm{CaO}$ linked to the abundance of carbonate matrix. The heat losses are to be bonded with the presence of water.

The matrix serves as a binder for both the coarse and fine mortar binder, is essentially represented by calcite. It is the product of the carbonation of the lime used in the preparation of the mortar.

Lime wasted with water and mixed with sand has the property of setting rapidly agglomerating inert particles, such as quartz [2].

\section{B. Broken tile mortar Analysis}

XRD shows that the binder of broken tile mortar is composed mainly of calcite (Fig. 2). The following bands of vibrations, indexed (1972.8217; 2098.1721; 2231.2363; 2281.3765; $2408.6553,2665.1414,3802.9368,3926.3586,838.8831 ; 1770.3326 \mathrm{~cm}-1$ ) are typical of calcite (Fig. 3).

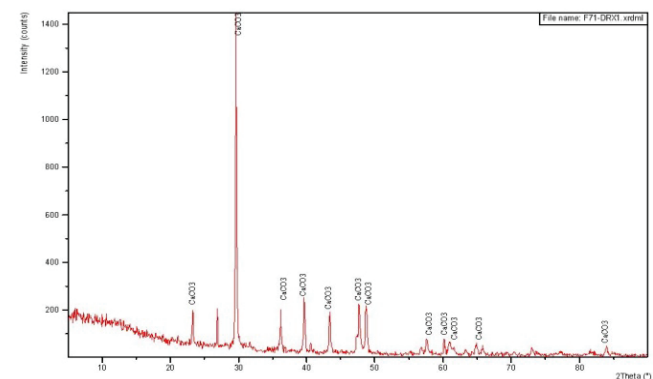

Fig.2: Diffractogram binder, mortar broken tile 


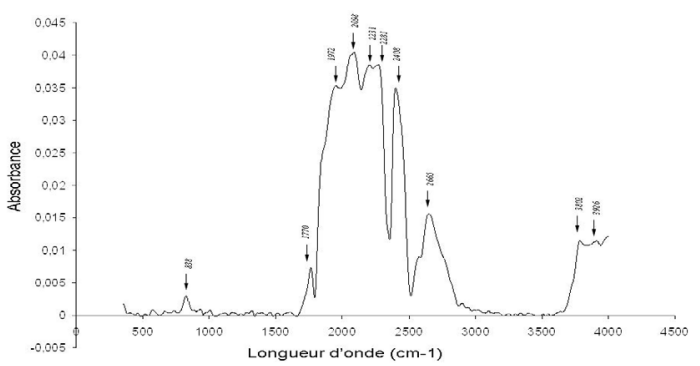

Fig.3: FTIR Analysis of the binder mortar broken tile

\section{Preparation of spare mortar prisms for restoration}

The preparation of the mortar through a mixture of lime, water, sand, with very precise proportions. Indeed, the lime mixed with water is mixed and left for several hours. Once the mixture is ready, a well-defined amount of sand is added. Prisms of $4 \mathrm{~cm} \mathrm{x} 4 \mathrm{~cm} \times 16 \mathrm{~cm}$ were made with different percentages of sand and lime (Table.1), the prisms are placed in the oven for $72 \mathrm{~h}$ at a temperature of $50^{\circ} \mathrm{C}$ for drying.

Table.1: Percentages of the used sand and lime mortar in preparation

\begin{tabular}{|c|c|c|c|c|}
\hline Mortars & $\begin{array}{c}\text { Percentage } \\
\text { of sand (\%) }\end{array}$ & lime (g) & sand (g) & $\begin{array}{c}\text { water } \\
(\mathrm{ml})\end{array}$ \\
\hline M1 & 20 & 400 & 100 & 800 \\
\hline M2 & 30 & 350 & 150 & 700 \\
\hline M3 & 40 & 300 & 200 & 600 \\
\hline M4 & 50 & 250 & 250 & 500 \\
\hline M5 & 66 & 170 & 330 & 300 \\
\hline
\end{tabular}

\section{A.1 Mortar of Replacement}

Table.2, below, gives the percentages of lime and sand used in the mortar spare and the drying period in the oven. We use this mortar the same refusal percentages of sand that are already found (table.2)

Table.2: percentages of sand and lime mortar of replacement

\begin{tabular}{|c|c|c|c|c|c|}
\hline $\begin{array}{c}\text { Mortar of } \\
\text { replacemen } \\
\mathrm{t}\end{array}$ & $\begin{array}{c}\text { Lime } \\
(\mathrm{g})\end{array}$ & $\begin{array}{c}\text { Sand } \\
(\mathrm{g})\end{array}$ & $\begin{array}{c}\text { Lime } \\
(\%)\end{array}$ & $\begin{array}{c}\text { San } \\
\mathrm{d} \\
(\%)\end{array}$ & $\begin{array}{l}\text { Drying } \\
\text { time ( } \\
\text { months })\end{array}$ \\
\hline FGR-1 & 636 & 364 & 63.6 & 36.4 & 2 \\
\hline FGR-2 & 636 & 364 & 63.6 & 36.4 & 3 \\
\hline
\end{tabular}

\section{A.2 The Mechanical tests on mortar spare FG-R}

The mechanical tests [5,6] aim to characterize the laws of behavior [4] materials (continuum mechanics). This law establishes the relationship between stress (pressure $=$ force $/$ area) and deformations (unit lengthening without dimensions). Table.3 summarizes the results of different mechanical tests (bending Fig.4 and Compressive Fig.5) conducted on the different parts of the mortar prisms.

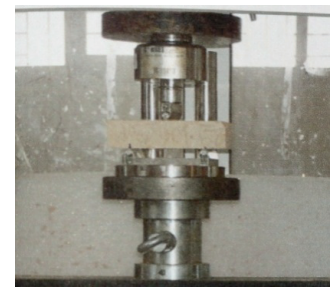

Fig. 4: bending test

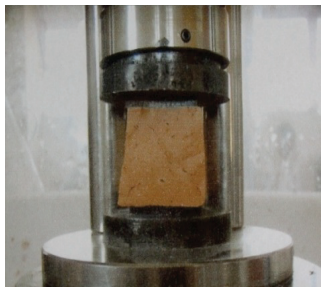

Fig.5: Compressive strength 
Table.3: values of flexural and compression of the Replacement mortar MR

\begin{tabular}{|l|l|l|l|l|l|l|}
\hline Prism & $\begin{array}{l}\text { Drying } \\
\text { time }\end{array}$ & $\begin{array}{l}\text { Mass } \\
\text { of the } \\
\text { prism } \\
\text { (g) }\end{array}$ & $\begin{array}{l}\text { Flexio } \\
\text { n (Ff) } \\
\text { in KN }\end{array}$ & $\begin{array}{l}\text { Flex } \\
\text { ural } \\
\text { MPa }\end{array}$ & $\begin{array}{l}\text { Compre } \\
\text { ssive } \\
\text { Fc) in } \\
\text { KN }\end{array}$ & $\begin{array}{l}\text { Compre } \\
\text { ssive n } \\
\text { MPa }\end{array}$ \\
\hline MR-1-1 & 2 month & 279.3 & 0.15 & 0.35 & $\begin{array}{l}1.45 \\
1.63\end{array}$ & $\begin{array}{l}0.91 \\
1.02\end{array}$ \\
\hline MR-1-2 & 2 month & 278.7 & 0.16 & 0.37 & $\begin{array}{l}1.22 \\
1.73\end{array}$ & $\begin{array}{l}0.76 \\
1.08\end{array}$ \\
\hline MR-1-3 & 2 month & 259.8 & 0.12 & 0.28 & $\begin{array}{l}1.49 \\
1.59\end{array}$ & $\begin{array}{l}0.93 \\
0.99\end{array}$ \\
\hline MR2-1 & 3 month & 310.4 & 0.32 & 0.75 & $\begin{array}{l}4.68 \\
3.27\end{array}$ & $\begin{array}{l}2.92 \\
2.04\end{array}$ \\
\hline
\end{tabular}

\section{Conclusion}

This study allowed us to characterize the mineralogy and chemistry of Roman mortar (the nucleus of the mosaic of broken tile and mortar Roman baths).

According to chemical analyzers, we found that the coarse and fine mortar matrix binder are represented mainly by calcite. The mineralogical analysis by X-ray diffraction of the coarse mortar and binder FG end, shows that they consist mainly of quartz and calcite with different proportions (with traces of feldspar and probably mica and dolomite).

The replacement mortar (FG) is comprised of $63.6 \%$ lime and $36.4 \%$ sand $(4.19 \%$ of the coarse component, $71.04 \%$ coarse sand, fine sand $24.22 \%$, and $055 \%$ fine fraction).

Mechanical tests exerted on the mortar spare FG show that the prism (MR2) exhibits good Compressive compared to other prisms because of a very slow setting.

Spare mortars developed in this study should be tested in order to ensure their performance.

\section{References}

[1] F. Davidovits, Les Mortiers de pouzzolanes artificielles chez Vitruve évolution et historique architecturale, Mémoire de D.E.A, Université Paris X-Nanterre, 1993.

[2] Dekayir, M.Amouric, J.Olives, C.Parron, A. Nadiri, A. Chergui, M. A. El Hajraoui, Structure and characterisation of the materials used in the building of Roman mosaics in Volubilis City (Morocco), C. R. Géoscience, vol.336, 2004, pp. 1061-1070.

[3] K.Bouassria, A.Ammari, A.Tayyibi, H.Bouabid, J.Zerouaoui,M. Cherraj, S. CharifD'ouazzane, The effect of lime on alumino-silicate and cement on the behavior of compressed earth blocks, J. Mater. Environ. Sci. 6 (12) (2015) 3430-3435.

[4] H. Bouabid, K. .Zine-dine, M. El Kortbi, S. Charif d'Ouazzane, O. Fassi-Fehri, Comportement mécanique non linéaire du mortier de terre stabilisée, Rev. Mar. Gén. Civ., nº 81, 1999, pp : 1619.

[5] Hakimi, N. Yamani, H. Ouissi, Résultats d'essais de résistance mécanique sur échantillon de terre comprimée, Matériaux et Construction, Vol.29, 1996, pp. 600-608.

[6] H.B. Nagaraj, M.V. Sravan, T.G. Arun, K.S. Jagadish, Role of lime with cement in long-term strength of Compressed Stabilized Earth Blocks, International Journal of Sustainable Built Environment (2014) 3, 54-61. http://dx.doi.org/10.1016/j.ijsbe.2014.03.001 